DOI: $10.15421 / 272005$

УДК 304(477)

\author{
Ірина Грабовська
}

Київський національний університет імені Тараса Шевченка, Украӥна

\title{
УКРАЇНСЬКІ ЕЛІТИ: \\ КОНФЛІКТ МІЖ «КОЧУБЕЇЗМОМ» І «МАЗЕПИНСТВОМ» (СПРОБА ФІЛОСОФСЬКО-СВІТОГЛЯДНОГО АНАЛІЗУ)
}

\author{
E-mail: grabovskai@ukr.net \\ ORCID ID: 0000-0002-7416-9541
}

\begin{abstract}
Анотація. Розглянуто проблему вибору українських еліт крізь призму понять «кочубеїзму»/«мазепинства» в історичній ретроспективі та перспективі існування незалежної самостійної української держави. Під «мазепинством» у сучасному українському соціогуманітарному дискурсі мається на увазі рух за виборення свободи для України, позбавлення української держави будь-яких форм колоніальної та неоколоніальної залежності. У філософському плані ця проблема розглядається якнайширше як питання співвідношення Добра і Зла для власної Батьківщини і народу. Поняття «кочубеїзм» («кочубеївщина») вживається для означення схильності до національної зради та самозради, сервілізм, ментальна настанова до рабства та підкорення чужим володарям. «Кочубеївщина» розглядалась Є. Маланюком як найгірший прояв малоросійства. Під малоросійством Є. Маланюк розумів «завжди поразку, ганьбу», програш, меншовартість особистості i нації в цілому. Конфлікт між ідейними та світоглядними установками «кочубеїзму»/«мазепинства» $є$ непримиренним. Проте робота із носіями цих ідей та світоглядних установок при певних умовах може привести як до позитивного для України як самостійної держави результату, так і до негативного. Зроблено висновок щодо необхідності рішучого вибору українством не лише європейськості, але і українськості задля збереження України та перемоги у боротьбі за власну свободу і незалежність.
\end{abstract}

Ключові слова: Україна, «кочубеїзм», «мазепинство», манкуртизм, малоросійство, неоімперія Кремля, визвольна боротьба, незалежність.

\section{Iryna Grabovska}

Taras Shevchenko National University of Kyiv, Ukraine

\section{UKRAINIAN ELITES: \\ CONFLICT BETWEEN «KOCHUBEISM» AND «MAZEPYNSTVO» (ATTEMPT OF PHILOSOPHICAL AND WORLDVIEW ANALYSIS)}

\begin{abstract}
The article deals with the problem of choosing the Ukrainian elites through the prism of the concepts of «Kochubeism» / «Mazepynstvo» in the historical retrospective and the prospect of the existence of an independent Ukrainian state. «Mazepynstvo» (after hetman Mazepa) in today's Ukrainian socio-humanitarian discourse refers to the movement for freedom for Ukraine, depriving the Ukrainian state of all forms of colonial and neo-colonial dependence. In philosophical terms, this problem is regarded as broadly
\end{abstract}


as a matter of balance between Good and Evil for one's own Homeland and its people. The term «Kochubeism» (after colonel Kochubey) is used to describe the tendency to national betrayal and self-betrayal, servility, mental attitude to slavery and sedition to foreign rulers. «Kochubeism» was considered by Eugene Malaniuk as the worst manifestation of Little Russia, not Ukraine ideology. This ideology Malaniuk understood "always defeat, shame», loss, the inferiority of the individual and the nation as a whole. The conflict between ideological and philosophical attitudes of «Kochubeism» / «Mazepynstvo» is irreconcilable. However, working with the bearers of these ideas of «Kochubeism» can, under certain conditions, lead to a positive result for Ukraine. The author of the article concludes that not only Europeanisms but also Ukrainianism is necessary for decisive choice by the Ukrainian people in order to preserve Ukraine and to win the fight for their own freedom and independence.

Keywords: Ukraine, «Kochubeism», «Mazepynstvo», mankurtism, ideology of Little Russia, neo-empire of the Kremlin, liberation struggle, independence.

Актуальність проблеми. Останнім часом в українському медійному просторі все частіше лунають думки аналітиків та експертів різного гатунку щодо того, що діюча влада та обраний президент, зрештою, як і всі попередні, не справляються із ситуацією в країні та на зовнішній арені. А це означає, що до влади повинні прийти люди з глибоким життєвим досвідом, наприклад, ті, хто зі зброєю в руках захищали й захищають країну. Отже, мова йде про те, що в Україні назріла потреба радикальної зміни еліт, оскільки політики повністю скомпрометували себе. Десять місяців нового президентства та уряду лише підтвердили ці усталені вже у масовій свідомості українців переконання, адже більшості обіцянок, виданих напередодні виборів, ще до цього часу не було виконано. Особливо це стосується обіцяного швидкого миру на Донбасі та припинення війни з РФ. Країною ширяться чутки про зраду національних інтересів верхівкою та частиною політичних еліт, що, зокрема, вилилось у серію протестних акцій «Ні - капітуляції!», які стрясали країну у 2019 р. До того ж не можна не помітити, що в сучасній Україні наростає протистояння в середині самих еліт, особливо політичних. Воно часто набуває суспільного резонансу 3 характеристиками «патріоти»/«зрадники», українські націоналісти/промосковська «п'ята колона», «бандерівці»/«русскомирівці» тощо. Зрештою, постколоніальними елітами України все ще не до кінця розв'язана проблема всіх подібних соціальних груп, яку умовно можна назвати конфліктом між «кочубеївщиною» («кочубеїзмом»), як схильністю до національної зради та доносительства чужому володареві, та «мазепинством», як прагненням до незалежності та сепаратизму, якщо розглядати цю проблему в історичній ретроспективі. В осучасненому вигляді ці характеристики набули означень, які точніше відповідають сьогоденню: «бандерівці»/«русскомирівці». I це справді одна 3 найактуальніших проблем сучасності, оскільки від іiі вирішення прямо залежить існування /неіснування України як окремої держави (насамперед) [17], незалежної самостійної нації, або перетворення iï на нову неоколоніальну спільноту під владою «долгого государства Путина» (В. Сурков) [18].

Аналіз останніх досліджень та публікацій. 3 приводу вищеокреслених проблем у сучасному соціогуманітарному дискурсі України та зарубіжжя існує величезна кількість літератури, в тому числі й наукової. У філософському плані проблема розглядається максимально широко, як розмисел над національним зрадництвом та національною незалежністю і самостійністю. А це, у свою чергу, обертається пошуками добра і зла для свого народу і Батьківщини, невід'ємними 
від визначення місця національних еліт як головного суб'єкта даного історичного процесу. Найтісніше заявлена вище проблема пов'язана із дослідженнями ідентичності, «українськості», як головної ознаки ідентичності, причому не лише етнічної чи національної, а саме колективної [Див., напр.: 4]. Проте не зводиться до неї. Проблема може ставитись й у розрізі національної самозради (як тема яничарства, манкуртства українців) та самозбереження [Див., напр.: 2; 3]. Проблема позиції та відповідальності еліт за те, що відбувається з країною, теж є цікавою у розрізі характеристик «кочубеїзму»/«мазепинства», принаймні як частина більш загального розмислу над викликами національного самовизначення. Так, наприклад, сучасний український дослідник М. Розумний характеризує існуючу українську еліту в термінах «імітаційної», «емігрантської», «ретроградної» [15, с. 62-71]. Виклики, які стоять перед українськими елітами у світлі подій, пов'язаних iз агресією РФ проти України, також знайшли висвітлення у сучасній українській соціогуманітаристиці [Див., напр.: 1; 6; 13; 15].

Щодо визначення понять, варто зазначити, що цей процес має велику історію, проте і сьогодні вони продовжують уточнюватись та поглиблюватись у науковій літературі [Див., напр.: 10].

Аналіз літератури дозволяє стверджувати, що є розуміння складності, пов'язаної з вибором майбутнього для країни постколоніальними елітами України, базоване на дослідженні історичних передумов ситуації, що склалася. Такий погляд на проблему представлений, наприклад, у дисертаційному дослідженні М. Рябчука «Дихотомія української національної ідентичності: історичні причини та політичні наслідки» [16]. У світлі проблем, піднятих М. Рябчуком, зазначені у даній роботі питання можуть бути розглянуті більш глибоко. Отже, на сьогодні маємо певний корпус філософських, політологічних, історичних, філологічних текстів, ідеї яких можуть бути використані як методологічний та теоретичний матеріал при дослідженні проблеми «кочубеїзму»/«мазепинства».

Метою даної статті $є$ спроба провести філософсько-світоглядний аналіз сутності конфлікту між «кочубеїзмом» і «мазепинством» еліт України 3 акцентом на його сучасному прояві.

Виклад основного матеріалу. Для 3'ясування сутності питання, насамперед, потрібно зупинитись на виявленні змісту основної термінології, що описує дану проблему. Отже, під «мазепинством», згідно із тлумачним словником, розуміється «політична доктрина гетьмана Мазепи та його ідейна спадщина щодо визволення України з-під російського колоніального ярма» // Рух за незалежність і свободу України. 2. icm. Зневажливий ярлик, вживаний по відношенню до національно-визвольного руху українців в Російській імперії; ...прагнення до відокремлення від Росії розглядалося російськими націоналістами як сепаратизм і зрада» [11].

Проте термін «мазепинство» давно вже має більш широке застосування. У сучасній Україні він отримав позитивні характеристики і означає боротьбу за волю, самостійність і незалежність України від Російської імперії в усіх їі втіленнях і реінкарнаціях. О. Оглоблін писав: «Мазепинство в московській мові стало символом українства. I тому українство не вирікається його ймення, хоч воно, може, й не цілком точно передає зміст новітнього українства. Навіть у часи після революції 1917 р. мазепинство в московському розумінні цього слова набрало ще актуальнішого значення» [14].

€. Маланюк, одна із найвидатніших постатей українського інтелектуального кола XX ст., стверджував: «О, допоки Росія $є$ Росією і Москва $є$ 
Москвою, навіть історіографічної «регабілітації» Мазепи ніколи не наступить, хоч би сталося ще кільканадцять октябрських чи февральських революцій! Ворог, якого національний інстинкт - при всім варварстві й дикунстві - був, є і буде найбільш живучий і безпомилковий, ворог... - на пункті Мазепи і мазепинства $\epsilon$ тотальнонепримиримий. I має цілковиту рацію. Мазепинство бо й $є$ яскравою протилежністю, яскравим запереченням, нещадним демаскуванням i найрадикальнішим ліком саме на Малоросійство. Бо що ж є Мазепинство, як не чинна свідомість Нації і інстинктовно звязана 3 тією свідомістю політична i мілітарна воля Нацією бути? Навіть за ціну Батурина чи Полтави» [12]. Ці слова залишаються актуальними i для нашого часу. «Майже століття минуло, а російський переляк перед українською державністю так i не пройшов. Як i таврування українців то «мазепинцями», то «бандерівцями» за відродження власної національної гідності. І прагнення «розібратися» з Україною також залишилося. Чи не ним продиктована почата Росією нинішня війна на Донбасі?» [5], - запитує Н. Ковальчук у статті із красномовною назвою «Російський погляд на українську державність: як не «мазепинство», то «бандерівщина»?»

Варто згадати і випад (інакше не назвеш!) проти України колишнього радника президента В. В. Путіна й одного 3 головних ідеологів теперішньої неоімперії Кремля В. Суркова проти українства, зроблений ним у інтерв'ю 2020 р. В. Сурков заявив, що «України немає, є українство. Борщ, Бандера, бандура є. А нації немає» [19].

Термін «кочубеївщина» («кочубеїзм») широко використовувався представниками політичної української еміграції для означення національного зрадництва, сервілізму та колоніальної підлеглості насамперед еліт України. Ю. Шевельов, перебуваючи в еміграції і роздумуючи про долю України, писав у 1954 році: «Три головні вороги України - Москва, кочубеїзм і провінційність» [20, с. 36]. Р. Корогодський, відомий шістдесятник і культуролог, зазначав: «Історична драма полягає в тому, що від феодальної відцентровості Україна не перейшла органічно до національної згуртованості, коли б національні інтереси були б понад усе. Та національний вектор дії у минулому не виник, у свою чергу, тому, що спрямований тиск сусідів був неадекватний опору. Вже відчувалася фатальна різновекторність військово-політичних зусиль України. На жаль, Україна від XVII ст. не знала моноконцептуальної доктрини, а стала ареною змагань різних поглядів щодо свого майбуття - отак утворилися сфери впливів. I найавторитетніші, найталановитіші українські діячі стали об'єктом особливої суспільної уваги. Почалася боротьба за їхні душі, формування осередків, амбіціозних кланів, куди затягувались ті чи ті діячі. Випробування на розрив, ротацію, трощення цілісності стало передумовою колоніального статусу України й прямої зради України, на що йшли ї̈ достойники. Комплекс кочубеїзму - вбивче й тверезе визначення цъього прочесу... (виділено - I. Г.)» [7, с. 304]. Є. Маланюк у творі «Малоросійство» зазначав, що «кочубеївщина - одне із найнегативніших проявів малоросійства» i що це явище не виникає i не зникає раптово. «Кочубеївщина то був плід довгих десятиліть» історичного існування України як поневоленої території та людності. Малоросійство, на думку цього відомого інтелектуала, завжди є пораженство і занепад, вторинність і меншовартість. «Малоросійство, хоч явище часте і кількісне, - найменш дотикало основну нашу національну масу - селянство (що нас не мусить особливо тішити, бо не маса творить історію). У нас малоросійство було завжди хворобою не лише півінтелігентською, але - й передовсім - інтелігентською, отже, поражало верству, 
що мала виконувати роль мозкового центру нації. I в цім - суть проблеми» [12], наголошує Є. Маланюк. «Малоросійство - це результат довгої історичної сепарації народу і нації, виділення 3 неї харизматів-провідників і нищення здатності спільноти до опору загарбникові та до самостійного існування. I це останнє $є$ найтяжчим наслідком колоніального минулого» [12]. I далі Є. Маланюк констатує: «Малоросійство бо - наша історична хвороба (В. Липинський називав ії хворобою бездержавности), хвороба многовікова, отже, хронічна. Ні часові застрики, ні навіть хірургія - тут не поможуть. Ї̈̈ треба буде довгі-довгі десятиліття - ізживати» [12].

Малоросійство як кочубеїзм $є$ «...хитливість, зрадливість, зрада i агентурність. Аж до часів наступних і нам найближчих» [12]. Запитуючи себе, що ж $\epsilon$ малоросійство за сутністю, автор вказує також і на ті методи, якими імперія виховує яничарство i манкуртизм у підлеглому народові. «Що ж таке малоросійство? Це також затьмарення, ослаблення $\mathrm{i}-3$ часом - заник історичної пам'яти. Тому i колишній Петербург, i теперішня Москва, розпоряджаючи зцентралізованим шкільництвом, таку велику вагу надавали й надають науці Історії...» [12]. Ці слова варто би було завчити напам'ять тим із наших сучасних очільників, які «вичищають» 3 українських вишів гуманітарні науки, особливо історію України, а зі шкіл - класику української літератури, в якій йдеться про історичні віхи боротьби українців за власну свободу, державність і незалежність.

У сучасній Україні від часів отримання нею незалежності в 1991 р. не припиняється боротьба між носіями «мазепинства» і «кочубеїзму», набуваючи різних означень, більше відповідних часові. За доказами ходити далеко не доводиться. Всі майже тридцять років самостійності державність України піддавалась сумніву з боку частини проросійськи орієнтованих еліт. I на сьогодні існують носії цієї позиції як серед партій, так і серед різних верств населення України. Показовими є і ті факти, що лише 44 \% населення країни переконані, що на Донбасі йде війна України з Росією. Зрештою, сучасні події та ставлення до них 3 боку українців - це вираз вічного конфлікту між свободою i рабством. Роздумуючи про долю Києва, ще один видатний українець, культуролог і публіцист Ю. Липа писав, що тим чинником, який став вирішальним у постанні Києва і всієї Київської держави, стало прагнення будівничих Міста бути вільними. Найбільшим нещастям для них було - стати рабами. «І це препишне і глибоке почуття свободи, волі лежить у глибині духовности Києва - Вічного Міста, лежить у глибині його великої культури. Тільки при такім відчуванні світу можна накладати на себе найбільші обов'язки, ставити завдання матеріальні і духові, творити і здобувати» [9], - стверджував Ю. Липа. На духовність народу повинна накладатись і моральність володарів. Такі володарі, на думку автора, були у стародавньому Києві. Як доказ наводиться «Поучення Мономаха», яке Ю. Липа розглядає як «зразок i мірило» достоїнства будівничих Києва i його володарів. Із цього документа доби «...виступає одна думка: будь хоробрий і перемагай життя у всіх його проявах» [9]. Ці переконання Ю. Липи щодо цінності свободи для русичів співзвучні розмислам одного з найвидатніших філософів сучасності, який, на жаль, відійшов у вічність, Сергія Кримського. Він писав: «На авансцені історії України завжди були люди вільного ратного духу; ніхто з них не бажав бути глядачем світової драми, усі хотіли бути тільки ії акторами. Ця стихія вільної самодіяльності особистості, без якої не можна було вижити в умовах кордонної цивілізації, що протистояла варварству степових набігів, живила і республіку козаків, і вольницю бурсаків, і вдачу мандрівних дяків та приватну ініціативу громадян у містах, яким 
було надано магдебурзьке право, і незалежний стан жінки як співтовариша у родині, «дружини»» [8, с. 113].

Висновки. Отже, з усього вищевикладеного випливає, що конфлікт між ідейним та світоглядним «кочубеїзмом» $\mathrm{i}$ «мазепинством», як двома доктринами та ментальними настановами, $€$ непримиренним, оскільки це дві радикально протилежні позиції щодо самостійного, незалежного i державного існування України. Проте можна працювати з людьми - носіями цих установок - $з$ більшою або меншою мірою ефективності. Очевидно, що на носіїв «кочубеїзму» розрахована і спрямована пропаганда російської влади. Натомість «мазепинці» це опора патріотичних та національно орієнтованих сил в Україні, зрештою, це основа іiі теперішньої державності. Українцям потрібен однозначний вибір. Сьогодні Україна зробила рішучий вибір на користь європейськості. Цю реальність варто би доповнити і таким самим рішучим вибором на користь українськості. I еліти повинні поставитись серйозно й відповідально до цього, адже сама ситуація гострого конфлікту вимагає до кінця усвідомленої позиції проводу. Отже, збільшення переконаних «мазепинців» $€$ одним із головних завдань сучасного українства. I рецепт того, як досягти поставленої мети, вже давно відомий. Він прописаний у творах багатьох достойників України - борців за національне визволення. Звернемося до одного із них. С. Маланюк писав: «Напружене творення Духової Суверенности - ось рецепт, що був, є і буде найбільш трудний, але й найбільш істотний і всеобіймаючий. Цей рецепт, до речі, виключає якнайгостріше - імітацію, деклямацію, патріотичну позу, барокове «здаватися, а не бути», як і всіляке «погрожування пальцем у чоботі» [12].

\section{References}

1. Grabovska I. (2017). The neo-imperiality of modern Russia as a historical challenge for Ukrainian post-colonial elites, Ukrainoznavchyi almanakh. K.: «Milenium+», no. 22, pp. 100-105 (in Ukrainian).

2. Grabovska I. M. (2016). The problem of national self-delusion in the Ukrainian realities of today, Zbiór artykułów naukowych. «Aktualne naukowe problemy: rozpatrzenie, decyzja, praktyka». Gdańsk, no. 6, pp. 93-97 (in Ukrainian).

3. Zemlianska A.V., Zotova V. H. (2019). The theme of janissary, manhood in poetry and essayist E. Malaniuk, Naukovi zapysky. Seriia: «Filolohichni nauky». Kropyvnytskyi: RVV TsDPU im. V. Vynnychenka, no. 184, pp. 45-53 (in Ukrainian).

4. Kysliuk K. (2018). Ukrainian identity: historical and cultural retrospectives and contemporary perspectives, Filosofska dumka, no. 3, pp. 48-65 (in Ukrainian).

5. Kovalchuk N. The Russian view of Ukrainian statehood: how not «Mazepynstvo», then «Bandera»? Prava Liudyny v Ukraini. Informatsiinyi portal Kharkivskoi pravozakhysnoi hrupy. URL: http://khpg.org/index.php?id=1427721945 (in Ukrainian).

6. Consolidation of Ukrainian into the post-colonial era: a monograph (2019). Kyiv: Pedahohichna dumka, 392 p. (in Ukrainian).

7. Korohodskyi R. (2000). Dovzhenko in captivity. Kyiv: Helikon, 347 p. (in Ukrainian).

8. Krymskyi S. B. (2009). Morning reflections. Kyiv: Maisternia Biletskykh, 115 p. (in Ukrainian).

9. Lура Yu. Kiev is an eternal city. URL: https://elib.nlu.org.ua/catalogue.html? catalogue $=81$ (in Ukrainian). 
10. Liubchenko V. B. MAZEPYNSTVO. Entsyklopediia istorii Ukrainy: T. 6: La-Mi. Kyiv: V-vo «Naukova dumka». URL: http://www.history.org.ua/?termin=Mazepynstvo (in Ukrainian).

11. Мазепинство. Тлумачний словник української мови у 20-ти томах. URL: https://goroh.pp.ua/\%D1\%82\%D0\%BB\%D1\%83\%D0\%BC\%D0\%B0\%D1\%87\%D0\%B5 $\%$ D0\%BD $\%$ D0\%BD $\%$ D1\%8F $\%$ D0\%BC\%D0\%B0\%D0\%B7\%D0\%B5\%D0\%BF\%D0 $\% \mathrm{~B} 8 \% \mathrm{D} 0 \% \mathrm{BD} \% \mathrm{D} 1 \% 81 \% \mathrm{D} 1 \% 82 \% \mathrm{D} 0 \% \mathrm{~B} 2 \% \mathrm{D} 0 \% \mathrm{BE}$

12. Malaniuk Ye. Little Russia. URL: https://zbruc.eu/node/90477 (in Ukrainian).

13. Modern Ukrainian: Civilization Challenges and Answers: Monograph. 2nd ed., ext. Kyiv: Milenium, 2019, 415 p. (in Ukrainian).

14. Ohloblyn O. Hetman Ivan Mazepa. Mazepa and Moscow. URL: https://www.facebook.com/uinp.gov.ua/posts/1311407725680525/ (in Ukrainian).

15. Rozumnyi M. (2016). Challenges of national self-determination. Kyiv: NIDS, 196 p. (in Ukrainian).

16. Riabchuk M. Iu. (2015). The Dichotomy of Ukrainian National Identity: Historical Causes and Political Implications. (Avtoref. dys.... kand. polit. n.). In-t politychnykh i etnonatsionalnykh doslidzhen im. I. F. Kurasa NAN Ukrainy, Kyiv (in Ukrainian).

17. World Hybrid War: Ukrainian Front: Monograph, ed. by V. P. Gorbulin. Kharkiv: Folio, 2017, 496 p. (in Ukrainian).

18. Surkov V. The long state of Putin. Novaia hazeta. URL: http://www.ng.ru/ideas/201902-11/5_7503_surkov.html (in Ukrainian).

19. Surkov stated that «there is no Ukraine, there is Ukrainian. Borsch, Bandera, bandura. There is no nation». URL: https://rubryka.com/2020/02/26/surkov-zayavyv-shhoukrayiny-nemaye-ye-ukrayinstvo-borshh-bandera-bandura-ye-a-natsiyi-nemaye/ (in Ukrainian).

20. Sherekh Yu. (1993). Over the lake. Bavaria. Ukraina. Nauka i kultura. K., 1993, issue 26-27, pp. 7-43 (in Ukrainian).

Received 21.02.2020

Received in revised form 27.02.2020

Accepted 02.03.2020 